\title{
Theological Motherhood:
}

\section{The Virgin Mother of God}

In most of the world's religions, sacred beings exist within familiar, usually familial, structures and relationships. Sexed and gendered deities, motivated by attraction and hostility, jealousy and friendship, parental and erotic love, are linked to one another as spouses, siblings, lovers, parents, and children. Complex and ambiguous affections characterize the relationships of gods and goddesses as well as those of men and women.

The most significant exceptions to these polytheistic norms are the great monotheistic traditions that arose in the Middle East. The God of Jews and Muslims is One, without child or consort, and theoretically without sex or gender-although that claim has been challenged and shaken. ${ }^{1}$ The God of Christianity also is One, but Christianity is an extraordinary monotheism based upon a divine relationship-not among its gods but within its God. The One of Christianity is Three, and although one is a Spirit, the others are a Father and a Son. The mother of the Son is not one of the Persons of the Trinity, although she is a member of the Holy Family, which also includes three persons. Jesus Christ participates in both triads: as the Second Person of the Trinity he remains

I. See, e.g., Nawal El Saadawi, "Man the God, Woman the Sinful," in The Hidden Face of Eve: Women in the Arab World, ed. and trans. Sherif Hetata (Boston: Beacon Press, I 982), chap. I2; also Judith Plaskow, Standing Again at Sinai: Judaism from a Feminist Perspective (New York: Harper \& Row, I 990). 
fully human, and as the son of Mary and Joseph, fully divine. Christian stories and the theologies constructed upon them leave ample room for speculation about the mother of God.

Such stories and speculation, and the cult of the Virgin Mother, have been crucial in the experience of Christian women and the formation of Christian ideologies of motherhood. The genius of Christianity is its incarnate god, born as a baby to a human woman in historical time. That event and that relationship stand at the center of Christian faith: Christ's humanity, taken from his mother, enabled him to save his fellow human beings. ${ }^{2}$ Physicality-birth, embodiment, death-is the source and secret of the Savior's relationship to all men and women. But the language of late antique philosophy, in which the credal definitions of Christianity were asserted, could not completely capture or define the figure of the human mother of Jesus or her role in the faith and experience of believers. Myths and stories and devotional practices flourished along with doctrine; some of the difficult questions in the history of Mary arise from discrepancies between the resounding abstractions of learned Mariology and the passionate expressions of devotion to a beloved mother who participates in the lives of her children.

The legends and the cult of Mary, as well as dogmatic statements about her nature and status, have long divided Christians, and division persists through the earnest ecumenical efforts of modern times. Such difficulties are not easily resolved, for they emerge not only in attitudes toward Scripture and tradition but in differences of nation, class, and culture. Attachment to Maryand the reverse, contempt for "Mariolatry" — runs very deep. Over two thousand years her cult has acquired songs, stories, liturgies, miracles, visions, memories, and works of art. It continues to exert

2. On the atonement, Anselm of Canterbury wrote: "The unbelievers deride our foolishness and claim that we offer God injury and scandal when we say he descended into the womb of a woman, was born of a woman, was nourished by milk and the food of human beings, and suffered fatigue, hunger, and thirst and died hanging on the cross between two thieves. .. . But if unbelievers would carefully consider how suitably the restoration of humanity was accomplished in this way, they would not laugh at our foolishness but with us would praise God's wisdom and goodness"; see "Cur Deus Homo" I.3, in S. Anselmi opera omnia, ed. F. S. Schmitt (Edinburgh: Thomas Nelson, 1946), 2:50-51. 
a powerful pull on the aspirations, experience, and imaginative creations of people all over the world. The magnetic field of the Virgin is shaped by her theological position, but its power is generated by the emotional and psychological status of the Mother of God and of Christian people. ${ }^{3}$ The figure of Mary evokes feelings about human mothers as well as faith in a divine Son.

In order to examine theological motherhood, an essential element in historical Christianity and in the history of motherhood, I begin by looking very briefly at the mother of Jesus in the Scriptures and at the construction of the figure of "the Virgin Mary" in early Christianity. ${ }^{4}$ From the abundant material available for the study of the medieval Mary, I have chosen to investigate the figure, status, and activities of the Virgin in selected religious literature of the twelfth century. At that time, devotion to Mary found expression in new artistic, liturgical, and literary works, including prayers, homilies, and treatises by men in religious life-notably, but not exclusively, by Cistercian monks. Along with contemporary autobiographical writings, these works shed light on attitudes toward God's mother, on feelings and assumptions about ordinary human mothers, and on the relationship between the two.

Twelfth-century European Christians also produced numbers of new stories and collections of stories about the miraculous appearances and activities of Mary. The miracle tales, which include significant folkloric elements, were for the most part "written" (or collected and transcribed) by clerical men but were shaped also by the interests and attitudes of people outside the cloister. Members of the literate elite gathered and retold tales that had circulated for centuries in Europe and the East, making them newly available to preachers and storytellers and through them to lay people. Individual tales and collections were formed in part by

3. Henry Adams puzzled over the force field of Mary; see "The Dynamo and the Virgin (1 900)," in The Education of Henry Adams (Boston: Houghton Mifflin, I9I0).

4. Theologically, of course, Mary's motherhood is significant only for Christians, but their long political and cultural dominance has made their ideologies influential for others as well-for Jews in medieval Europe, and for people all over the world after the fifteenth century. 
the tastes and responses of audiences, so they reveal certain values and assumptions of those who heard them. Because much of this literature deals with mothers and motherhood, it discloses ways in which the figure of Mary, and Marian devotion, shaped maternal ideologies and thus affected the experience of women and children in medieval Europe. Unlike other monotheistic religions, Christianity claims a central, sacred figure who is a woman and a mother; her history illuminates much that is perplexing in the history of motherhood in the West.

Students of Mary usually begin with Scripture, perhaps because her appearances in the New Testament are few and deceptively simple. They certainly do not provide a full or detailed picture of the mother of Jesus. Roman Catholics and Protestants differ over the interpretation of various texts but agree that the canonical Scriptures offer little information about the historical Mary or her relationship to the earliest Christian communities. For the New Testament writers, the mother of Jesus was primarily a vehicle for their Christologies, their community loyalties, and their special concerns-a pattern of writing about Mary that has endured for two thousand years.

In the earliest books of the New Testament, the letters of Paul, Mary is not mentioned by name. Writing to the Galatians in the context of the assertion of Christ's humanity and identification with the children of Abraham, Paul said, "God sent forth his Son, born of woman, born under the law" (Gal. 4:4). The characteristics of this nameless woman, even her sexual and marital status, were not of interest to the Apostle. Mark, earliest of the synoptic gospels, begins with Jesus' baptism and public ministry and has little to say about his mother. Of the three synoptic accounts of the scene in which Jesus asked, "Who is my mother, or my brothers?" Mark's is the most harsh and distinguishes most clearly between the physical kin of Jesus and the eschatological family of discipleship. Matthew and Luke soften the force of the distinction and the severity of the question. ${ }^{5}$

5. See Raymond E. Brown, Karl P. Donfried, Joseph A. Fitzmyer, and John Neumann, eds. Mary in the New Testament (Philadelphia: Fortress Press, I 978), pp. $5 \mathbf{I}-58$. 
Matthew presents the virginal conception of Jesus as the fulfillment of Isaiah 7:14: "Behold, a young woman shall conceive and bear a son." The prophecy was confirmed with the conception and birth of Jesus; nothing was said about Mary's continued virginity. References to younger children apparently did not contradict Matthew's understanding of the function of Mary's antepartum virginity or compromise the messianic status of Jesus. ${ }^{6}$ In later times these brothers and sisters were explained away, but for Matthew they were not problematic: Mary's virginity signified only in terms of her fullfilment of the prophecy.

The infancy narrative of Luke is the richest canonical source for the history of Mary and includes the unique passages in which she speaks her own words. It is difficult to imagine modern Christian piety, or the history of Western art, without the first two chapters of Luke: Annunciation, Visitation, Nativity-angels, shepherds, swaddling clothes. (Later Christians imagined that St. Luke heard these stories from Mary herself when he painted her picture, harvesting the fruit of her years of reflection on sacred history.) The author of Luke and Acts constructed a history of salvation from the conception and birth of Jesus through his ministry, Passion, and Resurrection and the foundation of the Church. He understood Mary's discipleship as a vital aspect of redemption. The assertion of her obedience to the will of God, which became such a powerful theme in the ideology of Christian motherhood, was derived mainly from Luke's sense of the response appropriate to divine command. He associated Mary with the poor in Israelhumble people who hear and obey God's word, who may not understand the marvels that occur but have the faith to believe and accept them. Luke's gospel established Mary as primary among the disciples, a significant theme in modern Mariology.?

The gospel of John contributed the figure of the Woman at the Cross. Entrusted to the beloved disciple, Mary became the mother

6. Ibid., pp. 83-87. See also John J. Saliba, S.J., "The Virgin-Birth Debate in Anthropological Literature: A Critical Assessment," Theological Studies 36 (1975), 428-454.

7. See, e.g., Patrick J. Bearsley, S.M., "Mary the Perfect Disciple: A Paradigm for Mariology," Theological Studies 4I (I 980), 46I-504. The "discipleship" model allows questions about virginity to be put to one side. 
of an eschatological household, of all faithful followers of Christ. In later medieval piety, the Woman at the Cross served as a model for weeping women, and the Pietà - the mother holding her dead son-became a central figure in art, liturgy, and the imagery of Christian motherhood. The salvific tears of mothers over lost children, generally sons, are persistent religious and sentimental elements in Western literature.

The most prolific early sources for the medieval cult of Mary were never accepted into the canon of the New Testament. The apocryphal gospels of the second and third centuries, which represented the passions and world views of groups excluded from "orthodox" Christianity during that period, reflected a growing interest in the family of Jesus. The central text for the construction of the medieval Mary, the second-century Protevangelium of James, supplied a full biography for the mother of Jesus. Born miraculously to the aged, barren couple Joachim and Anna, Mary was consecrated to virginity in infancy and spent a supernaturally holy childhood at the Temple in Jerusalem. At twelve, when even the holiest female became a potential source of pollution, she entered a chaste marriage with the aged widower, Joseph. Mary is the central figure in this complex and elaborate tale, as she is not in the canonical gospels, and her virginity is presented as essential to the history of redemption-even though consecrated virginity had no place in first-century Judaism, nor was virginity regarded as a desirable status for an adult woman. Nevertheless, by the second century C.E. it was sufficiently significant to certain Christians to be read back into the origins of their faith.

Although some Christians in the early centuries used the apocryphal gospels to nourish and support their insistence upon virginity and sexual asceticism, the same material supplied an idealized domesticity for the different interests of Christians a thousand years later. The great medieval cult of St. Anne was built out of materials in the apocryphal writings: Mary's mother became the exemplary, stable, and loving grandmother for a new age (see Chapter 5). Despite exclusion from the canon, these writings shared the power and immediacy of the Gospels and provided lavish embellishment for the creations of artists, preachers, and storytellers. The apocrypha made an important contribution to 
the imaginative resources of medieval Christians in the construction of theological motherhood.

During the early centuries of the development and expansion of Christianity, interest in Mary was shared among all classes, including the intellectuals. It was the task of theologians to define the role of Christ's human mother in the work of redemption and to participate as apologists in the mission of the churches. Christianity was a missionary faith, seeking to teach and convert and preach its good news to the world. The perception and presentation of Mary and her relationship to Christ were adapted to the religious and cultural systems of potential converts and transformed in turn by those systems.

When proselytizing Christians encountered a mother goddess, they responded by insisting on the One God who required neither mother nor consort. Christian monotheism was challenged by the Great Goddess of the ancient Mediterranean and the polytheistic pagan religions of Asia and Europe, and the exhortations of teachers and bishops did not always succeed in establishing a "pure" monotheism. The figure of Mary acquired characteristics of the old goddesses, whose ancient shrines were revived in some of Mary's holy places. ${ }^{8}$ The Virgin was credited with some of the capacities, if not the name, of a fertility goddess; in medieval Europe her girdle was prized above all other relics by women who longed to conceive a child. While preachers fulminated against the old religion, devotion to Mary increasingly resembled devotion to the goddess. In the late fourth century, for example, Epiphanius wrote disapprovingly of women who set up altars and made offerings of food and drink to Mary at shrines once sacred to Astarte. ${ }^{9}$

Christian apologists modified and elaborated their teaching in the face of challenges from many different theological systems and sacred figures. When they encountered gnostic dualism, with its relegation of the material world and of human bodies to the

8. In The Goddess Obscured (Boston: Beacon Press, 1985), Pamela Berger speculates about the gradual transformation of the ancient protectress of grain into various female saints and the Virgin Mary.

9. Epiphanius, Panarion 79.1, cited in Hilda C. Graef, Mary: A History of Doctrine and Devotion (New York: Sheed \& Ward, I963), I:73. 
sphere of darkness, they proclaimed the reality of the Incarnation. To emphasize and celebrate Christ's humanity, they stressed his "real" birth from a "real" woman. In the face of gnostic pessimism about world and flesh, they portrayed a material world created by the one good God and redeemed by the participation of the same God in Jesus Christ. Against pagan intellectuals, who tended to dismiss Hebrew and Christian Scriptures as exotic trash, they continued to insist upon the reality and dignity of the birth and death of Jesus. The One of Greek philosophy required no mother and was not subject to pain and suffering and humiliation: Hellenized intellectuals objected not to the oneness of the Christian God but to the humanity of Christ. Their conversion, like that of the gnostics, demanded that they be persuaded of the reality and necessity of the Incarnation, and thus of the birth of Christ to Mary.

Early apologists adjusted the figure of Mary to reinforce their developing doctrines of Christ, but their teachings did not always prevail in the sphere of symbolic representation-in art and worship. Mariology is an aspect of Christology; dogmatic theological assertions about Mary are derived from the implications of assertions about Christ. This is not necessarily true of expressions of devotion or of artistic and literary representations, where the primary focus is Mary herself. ${ }^{10}$ The approaches of the theologian, the artist, and the worshiper are not always compatible; their divergent paths may require adjustment or reconciliation. In the history of Christianity, Mariology has frequently followed in the path made by devotion. ${ }^{11}$

Io. Both kinds of statement are also "about" the hopes and wishes and fears of the believer, although theological argument may appear to be more "objective" than painting or praise.

I I. The title Theotokos, accepted at the Council of Ephesus in 43I, was used in Western liturgies long before its theological implications were addressed during the adoptionist controversy of the eighth and ninth centuries; in fact, such usage was one argument against adoptionism. Similarly, the Assumption of Mary was celebrated on August i 5 during the Middle Ages, even though the official dogma was not proclaimed until I950. The Immaculate Conception was debated by theologians and taught by preachers long before it was accepted officially. See Jaroslav Pelikan, The Christian Tradition: A History of the Development of Doc- 
Ignatius of Antioch, writing early in the second century C.E., was the first theologian to describe Mary's role in salvation. To counter the gnostic, docetic view of Christ as an impassible God who "assumed" human flesh without truly experiencing human life or death or affliction, Ignatius stressed Christ's double parentage from God and Mary: "There is one Physician, who is both flesh and spirit, born and yet not born, who is God in man ... both of Mary and of God, first passible and then impassible, Jesus Christ our Lord." ${ }^{12}$

The theme of the Second Eve, which became a persistent analogy in the theological construction of Mary's motherhood, appeared in the writings of Apostolic Fathers later in the second century. Paul had identified Christ as the Second Adam; for theologians after him, Mary was the Second Eve, whose obedience reversed the damage done by the disobedience of the first. By implication, just as Eve was Adam's partner in the Fall, Mary was Christ's partner in redemption. Irenaeus said: "For as Eve was seduced by the word of an angel to flee from God, having rebelled against his Word, so Mary by the word of an angel received the glad tidings that she would bear God by obeying his Word. . . As the human race was subjected to death through [the act of] a virgin, so was it saved by a virgin, and thus the disobedience of one virgin was precisely balanced by the obedience of another." ${ }^{13}$ The Eve/ Mary theme, tenacious in the history of Christianity, has reinforced the tendency of some men to perceive women as either "good" or "bad," and to venerate or punish them accordingly. ${ }^{14}$

Commentators on the analogy rarely remark that Eve was Ad-

trine, vol. 3, The Growth of Medieval Theology (600-1300) (Chicago: University of Chicago Press, I 978), pp. 68-69, I 72 .

12. Ignatius of Antioch, "Letter to the Ephesians" 7.2, p. I 8 I.

13. Irenaeus, "Adversus Haereses" 5.19, in Sancti Irenaei adversus haereses, vol. 2, ed. W. Wigan Harvey (Ridgewood, N.J.: Gregg Press, I965), p. 376.

I4. Commentators frequently present Adam as a good and well-meaning man with a tragic flaw, Eve as all bad-a wicked seductress, or an amoral woman ruled by her appetites. The Eve/Mary dichotomy reflects the phenomenon of "splitting" noted by psychologists: children tend to see their mothers as entirely good or frighteningly bad-to "split" the angry or punishing mother from the loving mother necessary for emotional health. 
am's wife but Mary was Christ's mother; little significance is attached to the difference in these relationships. ${ }^{15}$ Conflation of the roles and identities of consort and mother, typical of early and medieval devotion to Mary, characterizes the other great Marian theme adumbrated by the Apostolic Fathers: Mary as representation of the Church. Like the Church, she was steadfast and patient, enduring to the end, bride of Christ and mother of Christians. The blending of erotic and maternal characteristics, and of the roles of bride and mother, was a vital element in the construction of the medieval Mary and in her contribution to Christian ideologies of motherhood. Maternal-erotic language and imagery, accessible to the imagination of medieval Christians through these early theological metaphors, allowed the Virgin Mother to be associated with the Lady of romance.

While Mary became Christ's bride and consort as well as his mother, she was simultaneously transformed into the "ever virgin" Mary of patristic theology and ascetic spirituality. The biblical infancy narratives established the virginal conception of Jesus through the Matthean emphasis on prophetic fulfillment and the Lukan association of the virginity of Mary with the holiness of her child: "The Holy Spirit will come upon you, and the power of the Most High will overshadow you; therefore the child to be born will be called holy, the Son of God" (Luke I:35). The early Fathers wove Mary's virginity into their theological systems: Ignatius believed that along with Christ's birth and death it was one of God's three secrets from the Devil. ${ }^{16}$

Neither scripture nor theology could have constructed the medieval Virgin Mary without the energy and impetus of the ascetic movement of the third and fourth centuries. Athanasius, the premier theologian of the Incarnation, was also a great publicist of the monastic ethos. His Life of Antony was an essential model for the new heroes of the desert and the cell, for whom sexual asceticism was intrinsic to holiness and virginity a blessed condition to which human beings might aspire. In his treatise on the

I 5. Rosemary R. Ruether notes this point in Mary: The Feminine Face of the Church (Philadelphia: Westminster Press, I977), esp. pp. I9-23.

I6. Cf. Ignatius, "Letter to the Ephesians" I9.I, p. I93. 
Incarnation, Athanasius said that God "took our body, and not simply that, but from a pure and unspotted virgin ignorant of a man, a body pure and truly unalloyed by intercourse with men. ${ }^{\prime 17}$ Mary was not "simply" human but human in a particular waya virgin. In Athanasius's Letter to the Virgins, Mary-the firstcentury Jewish wife and mother-appeared in the guise of a fourthcentury Christian nun.

When new rules were developed for virtuous women in the post-Constantinian church, a new Mary was required for their edification, a Mary characterized by a quiet voice and demure behavior. Jerome interpreted her terror of the Annunciation as offended modesty: "She had never been greeted by a man before." 18 The Fathers agreed that Christ's birth from a virgin transformed motherhood. Eve's children were born in pain and anguish; Mary's triumph lifted that ancient curse. Unlike married women, said Jerome, virgins had the possibility of conceiving Christ, and the most deserving might aspire to the ultimate prize: "He having been conceived grows to manhood, and as He becomes older regards you not as His mother but as His bride. ${ }^{\prime 19}$ Mary became the spouse not of the old man, Joseph, but of the young man, Jesus. The metaphors of filial, maternal, and erotic love are closely entwined; the romantic character of Mary's motherhood is no less passionate for its association with virginity.

The ideology of spiritual motherhood, firmly established in monastic communities and spheres of influence by the late fourth century, was developed in imitation of the fruitful motherhood of Mary. Even though it was precisely her physical motherhood that accomplished the Incarnation, still - and increasingly - the differences, not the similarities, between the birth of Christ and all other births were elaborated and celebrated. As the ascetic ideal spread and flourished, it became impossible to imagine God's mother giving birth like other women. Persistent gnostic influences may have contributed to the atmosphere of difference sur-

17. Athanasius, "On the Incarnation of the Word" I.I 8, in Contra gentes and De Incarnatione, ed. and trans. Robert W. Thomson (Oxford: Clarendon Press, I 97 I), p. I 53.

I8. Jerome, Select Letters, 22, p. 147.

I9. Ibid., p. I 49. 
rounding Christ's Nativity. In Ode 19 of the second-century Syrian Odes of Solomon, the "masculinity" of Mary reinforces a sense of her awesome power:

So the Virgin became a mother with great mercies.

And she labored and bore the Son but without pain,

because it did not occur without purpose.

And she did not seek a midwife,

because he caused her to give life.

She bore as a strong man with desire,

and she bore according to the manifestation,

and possessed with great power.

And she loved with salvation,

and guarded with kindness, and declared with greatness.

Hellelujah. $^{20}$

To medieval Christians it became increasingly obvious that Mary was always a virgin-during and after, as well as before, the birth of Jesus. Sexual activity was unthinkable for her, as was a ruptured hymen: perfection was incompatible with the loss of bodily integrity, and despite evidence to the contrary (such as menstruation), medieval people believed that the hymen served as a kind of seal. ${ }^{21}$ Mary gave birth without the pain, immodesty, and disarray of ordinary female experience, and the miraculous nature of Christ's birth was emphasized ever more strongly. In the fourteenth century, Birgitta of Sweden (see Chapter 5) described her own vision of the Nativity, in which Mary knelt reverently in prayer while the stable filled with light from the divine infant. ${ }^{22}$

20. The Odes of Solomon, in The Old Testament Pseudepigrapha, vol. 2, ed. James H. Charlesworth (New York: Doubleday, I 985), pp. 752-753. Gail Paterson Corrington discusses the male and female metaphors of Ode 19 in "The Milk of Salvation: Redemption by the Mother in Late Antiquity and Early Christianity," Harvard Theological Review 82 (I989), 393-420.

2 I. See Clarissa W. Atkinson, "Precious Balsam in a Fragile Glass': The Ideology of Virginity in the Later Middle Ages," Journal of Family History 8 (1983), I 3 I-I43; also Charles T. Wood, "The Doctors' Dilemma: Sin, Salvation, and the Menstrual Cycle in Medieval Thought," Speculum 56 (I98I), 710-727.

22. Birgitta of Sweden, Den Heliga Birgittas Revelaciones, ed. Birger Bergh, SUSF, ser. 2, vol. 7, Lat. skrifter (Uppsala: Almqvist \& Wiksells, 1967) chap. 21, pp. I87-I90. 
Artists and their patrons were inspired by Birgitta's revelation, which shaped later representations of the Nativity. Birgitta was the mother of eight children; her vision demonstrated radical discontinuity between Mary's experience and her own.

Learned Christians taught, with Ambrose, that "he who came from the Father took flesh from the Virgin; he took this disposition from his mother so that he could bear our infirmities. ${ }^{\prime 23}$ Mary might be unlike all other mothers in her virginity and mode of giving birth, but the conception of Jesus was in other respects compatible with the paradigms of Aristotelian biology. Fathers were thought to be the active agents in procreation, and like other children, Jesus received his spirit from his Father, his flesh from his mother. Over time, Christian thinkers came to believe that human conception was clouded by original sin, transmitted in the male seed from father to child. Christ, having no human father, was conceived without original sin. In response to the Pelagians, Augustine strengthened the identification of original sin with sexuality and with the father's seed. Augustine was primarily concerned with sin, grace, and the unity of the human race, but he worked out these themes within an inherited framework of biological opinion. Within that system it was easy to understand that Christ was joined to Adam, and thus to all human beings, through his mother's flesh, and to God through his paternity. Augustine persisted in the belief that a father was the parent of a child's spirit, even though his own experience indicated something quite different. He repeatedly praised his mother's role in his conversion, but neither contempt for his father's earthbound materialism nor appreciation of his mother's spiritual gifts forced him to revise his intellectual and theological heritage concerning gender, spirit, and flesh.

In the early fifth century, long-standing disagreement about the two natures of Christ crystallized in sharp controversy over the Marian title Theotokos (bearer of God). The Council of Ephesus was convened in $43 \mathrm{I}$ in part to determine whether Mary carried and gave birth to the true God or simply to the human Jesus.

23. Ambrose, "Explanatio Psalmi 6I" 5, in Sancti Ambrosii opera, pt. 6, ed. M. Petschenig (Leipzig: G. Freytag I919), p. 380; CSEL, vol. 64. 
Among the sparks that set off the conflict was an inflammatory sermon preached in Constantinople by Proclus, who venerated Mary as Theotokos. The imagery and language of his sermon display the high Mariology of some eastern Christians:

We have been assembled by the holy Mary, the stainless jewel of virginity, the rational paradise of the second Adam, the workshop of the unity of the natures, the scene of the saving contract, the bridal chamber, in which the Word espoused the flesh ... the only bridge between God and men. . . ${ }^{24}$ Emmanuel has, indeed, opened the gates of nature, because he was a man, but he did not break the seals of virginity because he was God ... he was born as he was conceived; he had entered without passion, he went forth without corruption. ${ }^{25}$

The theologians' enthusiasm for the title Theotokos, which reinforced the unity of the two natures of Christ, was echoed by crowds of monks and lay people who shouted in the streets while the council deliberated. The crowds were rallied by ecclesiastical pressure groups, but their rowdy participation may also be associated with Ephesus itself-the old city of Diana, with its tradition of sacred female power.

In the wake of the council, enthusiasm for Mary was proclaimed in passionate prayer and preaching, and images of the Virgin were placed in churches and added to shrines once sacred only to Christ and the apostles. Representations of the Adoration of the Magi, in particular, served as opportunities to depict in stone and paint the majesty of God's mother. ${ }^{26}$ In the large churches of the East and of Byzantine Italy, the sovereignty of the Virgin was celebrated in monumental statues of the Madonna and Child, frontal sculptures presented in an attitude and style denoting majesty. In the great mosaics of Ravenna, Christ and Mary share the glory of earthly and divine kingship with the imperial family.

With the expansion of Charlemagne's empire and the Carolingian Renaissance of the ninth and tenth centuries, the influence

24. Note that Mary, not Christ, is the "bridge."

25. Proclus of Constantinople, "Oratio I, De laudibus Sanctae Mariae," cited in Graef, Mary, I: 102.

26. See Marie-Louise Thérèl, "Les visages de Marie," Bullétin de la Société Française d'Etudes Mariales 33 (I975-76), 5-20. 
of Italian and other Byzantine works of art began to be reflected in the sculpture and architecture of western Europe. The grandeur of Christ and Mary suited the theology and spirituality of the early Middle Ages, when Father and Son were closely identified, and Christ was preeminently king and judge, distant from this world and its people. Christ reigns in majesty or presides over the Last Judgment on the portals of Romanesque churches, and his mother is portrayed as Queen of Heaven. In French Romanesque wood sculptures of the Madonna and Child, Mary's lap offers not maternal comfort and intimacy but a throne for the God-child; both figures are majestic and mature, and both face forward. ${ }^{27}$ Images of Mary reflect the lordship of her divine son. Maternity remained the source of her power, but its majesty and uniqueness were stressed at the expense of intimacy and familiarity. Early medieval Christians depended on approachable local saints and their tangible relics for comfort and protection; Mary was the queenempress, presiding over heaven and earth with the Father and his awe-inspiring Son.

However, the mighty and remote Queen of Heaven of the year I ooo represented only one strand in the construction of the mother of God. Within that complex figure monks found their Virgin Mother, theologians their Theotokos-key to Incarnation and Redemption-and Christian people, including monks and theologians, a sacred maternal being who incorporated certain powers and qualities of the ancient goddesses. The protean "Mary" changed her shape to accommodate the requirements of her devotees. Early theologians, artists, and worshipers painted her portrait with a brush broad enough to leave a rich and ambiguous legacy to medieval people. When the society and religious culture of Europe entered a period of radical change at the beginning of the second millennium C.E., Mary began to participate in new ways in Christian faith and experience.

By the latter part of the eleventh century, profound alterations were under way in almost every aspect of European society and

27. On these figures and their significance, see Ilene Forsyth, The Throne of Wisdom: Wood Sculptures of the Madonna in Romanesque France (Princeton, N.J.: Princeton University Press, 1972). 
culture. Trade increased within Europe and around the Mediterranean, enhancing the growth and prosperity of cities and towns; new urban centers, in turn, fostered commerce in many kinds of goods. More fundamental, perhaps, were the accumulated effects of long-term developments in agriculture and technology. Eleventh-century Europeans ate more food and better food than their ancestors. Thanks to higher agricultural yields and improved techniques in animal husbandry, they consumed more vegetable and animal protein and dietary iron. Women conceived more easily, carried more babies to term, and kept more children alive to adulthood. Agricultural surpluses appeared in some areas, stimulating markets and fairs that brought people and goods together. Urban and commercial growth encouraged sociability and stimulated political and cultural change; for the first time in half a millennium, opportunities for education and cultural expression existed outside of monasteries. Artists and artisans exerted themselves in the construction of large churches in new towns and cities; schools grew up around teachers and libraries attached to cathedrals. In relation to the history of Mary, the rebirth of literacy was especially significant. Writing and texts began to dominate many forms of discourse, with implications for politics, theology, and culture $^{28}$-including the construction and circulation of new literary representations of the Virgin Mary.

In the late eleventh century, the "Church"-meaning, in this instance, significant members of the Roman Curia and their supporters among bishops and monks all over Europe-undertook a major campaign of self-criticism, reform, and reorganization. Pope Gregory VII and his associates determined to put an end to the domination by lay magnates that had characterized early medieval ecclesiastical polity. Concentrating on the issues of lay investiture, simony, and clerical celibacy, they set out to purify the Church, to distinguish it sharply from "the world," and to make its clergy worthy to lead all Christendom. The Gregorian reformers believed that the Church and its clergy ought to be dissociated as

28. See Brian Stock, The Implications of Literacy: Written Language and Models of Interpretation in the Eleventh and Twelfth Centuries (Princeton, N.J.: Princeton University Press, 1983). 
far as possible from worldly things and worldly people, including women and families.

In the reformers' vision of the Church, it was inappropriate for priests to marry or have children. Most of the leading Gregorians were monks, and they wanted the entire clergy to be monastic in ethos and ideology. Peter Damien used Mary's virginity to argue for clerical celibacy: "For because the Lord's body grew together in the temple of a virgin's womb, even now he asks of his ministers the purity of continence." Assuming that Christ's earthly father as well as his mother was a virgin, Damien asked, "By whom then, I ask you, does he want his body to be handled now except also by virgins?" ${ }^{29}$ In art, theology, and devotion the Lord's body became an object of enormous interest. The meaning and mode of the Eucharist were subjected to intense discussion during the twelfth century, when renewed emphasis on the Mass reinforced respect for the power and sacredness of those who handled Christ's body. In all aspects of secular and religious life, the Gregorian reformers stressed differences between clergy and lay people. They promoted separate clerical living arrangements and special legal and educational systems and institutions, adamantly resisting secular interference in the lives and business of the clergy.

In the century after the reform, the Roman Church grew steadily more powerful, more ambitious, more centralized, and more "rational" in its procedures. The popes tightened their own authority within the Church, which sought first independence and then authority in the world outside-authority based not only on reform but also on the rediscovery of Roman law and the development of canon law and ecclesiastical procedures. As one element in its program of centralization, legalization, and order, the Curia claimed exclusive control over the making (or recognition) of saints; shrines and monasteries were no longer permitted to canonize local wonder-workers. Popes and reformed religious orders, with their international identity and membership, encouraged increased attention to the universal figures of Christ and Mary. The centralized church of the twelfth century and the new "Chris-

29. Peter Damien, Opuscula I 8.1, 17.3, in S. Petri Damiani opera omnia, vol. 2; PL I 45, col. 384 . 
tendom" of the Crusades required unifying symbols. Mary gradually took the place of old, familiar, and beloved local saints and acquired some of their characteristics-intimacy, immediacy, and parental concern for the affairs of her children.

The passionate, single-minded enthusiasm of the reformers helped to bring about a widespread revival in the life and piety of monastic institutions, with corresponding changes in the form and feeling of prayer. In the ninth century most worship revolved around collective recitation of the liturgy; hymns and prayers were based mainly on psalms. By the eleventh century devout monks had begun to create new forms, making use of tender, pathetic, personal language and imagery. They paid attention to their own feelings and to the imagined feelings of Christ and Mary and the saints, dwelling less on the majesty of the distant Lord Christ than on the sufferings of the man Jesus and his family and friends. Inevitably, there was a corresponding shift in the perception and praise of Mary. Near the end of the century, Anselm of Canterbury composed a meditation on the Virgin that worked through fear, shame, and sadness toward love and joy. Anselm exulted in his own relationship, through Mary, with his Savior:

The mother of God is our mother. The mother of him in whom alone we hope and who alone we fear is our mother. The mother, I say, of him who alone saves us, alone damns us, is our mother... .

If you, lady, are his mother, then are not your other sons his brothers? ... .

Therefore our judge is our brother. The saviour of the world is our brother. Finally our God is made our brother, through Mary... .

Mary, how much we owe to you! Lady mother, through whom we have such a brother, what thanks, what praises, should we return to you $?^{30}$

The traditional theological emphasis on Christ's salvific humanity exploded in passionate gratitude to Mary as mother-Christ's mother, but the mother also of those to whom she had provided hope for redemption.

30. Anselm of Canterbury, "Oratio 7," in Opera omnia (Schmitt) 3:23-24. 
The affective piety of the eleventh and twelfth centuries was in part a product of the Gregorian reform and, like the reform itself, was monastic in origin and ethos. R. W. Southern noted that Anselm's friend and biographer Eadmer of Canterbury was the first to use the rhetoric of "historical rhapsody" to argue for Mary's immaculate conception, deducing the "necessity of otherwise unknown historical events from arguments of theological propriety." ${ }^{31}$ The archbishop's nephew, another Anselm, was involved with the production of one of the earliest English collections of "Miracles of the Virgin." ${ }^{32}$ The literature of Marian devotion was generated in reformed monasteries in England and on the Continent, in intense communities of men who loved Mary, Jesus, and one another.

Anselm of Canterbury was only one of many twelfth-century monks who manifested passionate adoration of the Virgin in sermons, prayers, meditations, and theological treatises. Chief among her monastic devotees was the Cistercian Bernard of Clairvaux, who believed that God became human so that human beings could love God. The human motherhood of Mary, essential to Bernard's theology of love, was completely different from that of ordinary women. According to Bernard, Mary rejoiced in childbirth "not for itself, but in him whom she has borne. God . . was careful to prepare her on earth with a special grace; whereby she conceived undefiled beyond all telling and unspoiled she gave birth. Only this mode of birth was becoming to God-to be born of a virgin." ${ }^{33}$ To Bernard, the humility of Mary reflected the humility of Christ, who became the lowest and weakest of crea-

3I. R. W. Southern, St. Anselm and His Biographer (Cambridge: Cambridge University Press, 1963), p. 289. Eadmer argued that since God could and should have created Mary without sin, he must have done so: "De conceptione B. Mariae Virginis." S. Anselmi opera omnia, vol. 2, PL 159, col. 305.

32. Southern argues that the first English collections were made in monasteries with a "strong old English tradition by men admiring Anglo-Saxon piety"; see "The English Origin of the Miracles of the Virgin," Medieval and Renaissance Studies 4 (I959), I 77 .

33. Bernard of Clairvaux, Magnificat: Homilies in Praise of the Blessed Virgin Mary by Bernard of Clairvaux and Amadeus of Lausanne, trans. Marie-Bernard Saïd and Grace Perigo (Kalamazoo, Mich.: Cistercian Publications, I 979), 2.1 2, p. I 5 . 
tures-a little child whose helplessness and lowliness was manifested in obedience to his mother. "Just imagine! Double marvel! God does what a woman says-unheard-of humility. A woman outranks God-unparalleled sublimity!"34

Bernard believed that the daughter, Mary, reconciled her mother, Eve, with the Father and thus liberated all women from "the hard burden and heavy yoke laid on every daughter of Eve. If they bear children, they are in anguish: if they are childless, then they are cursed." All mothers ought to rejoice in Mary's work, but "you more especially, mother Eve, exult." ${ }^{35}$ Because of Mary, men no longer condemn and reproach women: "Eve is pardoned through her daughter, and the complaint of men against women is put to rest." ${ }^{36}$ The "pardon" remained theoretical: Bernard always distrusted women. He discouraged the spiritual direction of nuns by Cistercian monks on the grounds that "to be always in a woman's company without having carnal knowledge of her-is this not a greater miracle than raising the dead? You cannot perform the lesser; do you expect me to believe that you can do the greater? " 37

This greatest of Mary's praise-singers was the son of a remarkable mother who dreamed, discerned, and shaped his destiny. According to the Golden Legend, Bernard's mother Aleth refused for her children their aristocratic legacy of pride, luxury, and war: "As long as they remained in her care she bred them for the cloister rather than for the court, giving them coarse and common goods as if they were to be sent off to the desert." Defying the noble custom of employing wet nurses, she would not "allow her children to be suckled at the breasts of other women, but imparted to them, with the maternal milk, the nature of the mother's vir-

34. Ibid., I.7, p. I I.

35. Ibid., 3.7, p. 38; 2.13, p. 16.

36. Bernard of Clairvaux, "Sermo in nativitate Beatae Mariae," in S. Bernardi opera, vol. 5, ed. Jean Leclercq and Henri Rochais (Rome: Editiones Cistercienses, I968), p. 278.

37. Bernard of Clairvaux, On the Song of Songs III, sermon 65.4, trans. Kilian Walsh, O.C.S.O., and Irene M. Edmonds (Kalamazoo, Mich.: Cistercian Publications, 1979l, p. 184. See Sally Thompson, "The Problem of the Cistercian Nuns in the Twelfth and Early Thirteenth Centuries," in Medieval Women, ed. Derek Baker (Oxford: Basil Blackwell, I 978), pp. 227-252. 
tue." ${ }^{38}$ Aleth died when Bernard was seventeen. He entered a period of depression and disillusion from which he was restored, apparently, by commitment to the spirit and tough regime of the Cistercians and by a passion for the Virgin Mother. According to contemporary stories, Mary rewarded his devotion with three drops of her milk. ${ }^{39}$

Bernard's sister, Aleth's only daughter, married despite her mother's intention to consecrate all her children to religious life. When she visited her brothers in the monastery, Bernard would not look at her, and another brother called her a "bedizened dunghill." Bursting into tears, the unfortunate woman reminded them that Christ died for sinners and that they as Christ's servants were responsible for the care of souls: "If my brother despises my flesh," she said, "let not the servant of God despise my soul." ${ }^{40}$ The story is a vivid representation of Cistercian ambivalence; in spite of Mary's victory over the curse of Eve, women were feared and despised as sources of evil unless they were consecrated virgins or the mothers of exceptional men. Caroline Walker Bynum has demonstrated that although Cistercian men frequently attributed to themselves the "feminine" and "maternal" characteristics of tenderness and patience, such attributions occurred most often in the context of issues about authority. ${ }^{41}$ Their use of the vocabulary of motherhood reveals some of the assumptions and expectations that surrounded idealized motherhood in the twelfth century but has little to do with actual mothers.

The English Cistercian Aelred of Rievaulx composed loving, personal meditations on Christ and Christ's lovers, including the Virgin. The Gospels offered little to nourish the Cistercian hunger for intimate details of Jesus' life, and the monks tended to focus on certain familiar incidents to the point of sentimentality. Aelred

38. "Saint Bernard," in Golden Legend, p. 465.

39. Cf. the fresco by Filippino Lippi, The Vision of St. Bernard, from the Bardi church in Florence, reproduced by Marina Warner in Alone of All Her Sex: The Myth and the Cult of the Virgin Mary (New York: Vintage Books, I983), fig. 3 I.

40. Golden Legend, p. 470.

4 I. Caroline Walker Bynum, "Jesus as Mother and Abbot as Mother: Some Themes in Twelfth-Century Cistercian Writing," in Jesus as Mother: Studies in the Spirituality of the High Middle Ages (Berkeley: University of California Press, I983), pp. I Io-I 69 . 
employed a meditation on Jesus at twelve to ask questions about the relationship of mother and son. Why was Jesus so inconsiderate as to disappear during the visit to Jerusalem? Why did Mary worry, like an ordinary mother, when she knew he was God? On the other hand, why was she so careless as to lose sight of the precious boy? Why (and this, of course, is the Christological point) was God a child at all, and thus subject to parents? Who took care of him during the three days' separation? "Who provided you with food and drink? Who made up a bed for you? Who took off your shoes? Who tended your boyish limbs with oil and baths?"42

The subject is a boy of twelve, almost an adult by medieval standards. The care and service mentioned are those required by a toddler, but they serve the author's purpose by creating a context of concrete tenderness: "not theological speculation but devotion; not something to sharpen your tongue but something to arouse your affections." ${ }^{43}$ Vivid reminders of the physical presence of a young child awaken lively thoughts and feelings, and this is a major impulse and purpose of affective piety. Taking hold of our response to a child too young to remove his own shoes, Aelred glides without interruption into another set of powerful images and feelings-the erotic. He attributes to Mary, discovering her son among the rabbis, the language of the Song of Solomon (3:4): "'I found,' she says, 'him whom my soul loves. I held him fast and would not let him go.' "44 Maternal tenderness and sexual yearning - the passions aroused by Christ's humanity-carry the Christian closer to God.

Guerric of Igny wrote a series of sermons dealing with themes of childhood and maternity. Even more than his fellow-Cistercians, he perceived women in terms of extreme good and evil. Since mothers were defined as good, Eve could not be a mother at all; "not so much a mother as a stepmother since she handed on to her children an inheritance of certain death. ... She is indeed called the mother of all the living, but she turned out to be more

42. Aelred of Rievaulx, "Jesus at the Age of Twelve" 6, trans. Theodore Berkeley, O.C.S.O., in The Works of Aelred of Rievaulx, vol. I, Treatises: The Pastoral Prayer (Spencer, Mass.: Cistercian Publications, I97I), p. Io.

43. Ibid., I I, pp. I 3-I 4 .

44. Ibid., 8, p. I I. 
precisely the murderer of the living ... since the only fruit of her child-bearing was death." ${ }^{\prime 45}$

The conventional opposition of church and synagogue was especially vicious in Guerric's usage. He identified these female personae with the two mothers in the story of Solomon and the contested infant (I Kings 3:16-28): "The evil harlot in her rivalry would rather the infant were killed than given to me alive, but the judgment of our Solomon ... made no mistake in finding the mother. Give to the Church, he says, the living infant, for she is its mother." Like church and unlike synagogue, a conscientious abbot is a good mother. Guerric promised to "show myself a mother by love and anxious care ... this name of mother is not restricted to prelates, although they are charged in a special way with maternal solicitude and devotion." 46

The Virgin was the best mother, and Guerric preached on the feast of her purification: "Neither conception nor childbirth violated your integrity.... Why then, as if you had suffered something of what is the common lot of woman in conceiving or giving birth, do you thus seek the remedies of a cleansing which was provided for woman's weakness? ${ }^{\prime 47}$ That question was frequently asked, mainly in order to point up the vast difference between Mary and all other women, and the answer was always the same. Mary submitted to purification out of her extraordinary humility - the quality, above all others, that women were urged to emulate.

It is sometimes asserted that medieval women found strength and support through identification with the maternal status and power of the Virgin. This may be true, but it cannot be demonstrated from the writings of twelfth-century Cistercians. These works were intended for monks, and sometimes for nuns, and were probably unknown or irrelevant to laywomen-that is, to mothers, whose concerns were not of interest to the authors. It would have been more natural for laywomen to identify with Eve, charged by Cistercians with bringing death into the world, than

45. Guerric of Igny, Liturgical Sermons (Spencer, Mass.: Cistercian Publications, I $97 \mathrm{I}), 2: 168$.

46. Ibid., $1: 52$.

47. Ibid., p. I 20. 
with the "Mary" of these texts. In reality, of course, the death that came into the world in medieval childbirth was the death of women and their infants, but that reality does not intrude in these writings. For these twelfth-century Cistercian male authors, "true" motherhood belonged to the Church, the Virgin, and themselves.

At least one twelfth-century woman did write extensively about Mary, a woman who was theologian and visionary, counselor and healer, abbess and preacher. Hildegard of Bingen held strikingly original views on obstetrics and gynecology (see Chapter 2). When she wrote about the mother of God, however, she was concerned not with Mary's individual human nature and maternity, but with her theological status in relation to the Creation and Redemption of the world. Barbara Newman describes Hildegard's Mary as "the capstone of the arch formed by the celestial foreshadowing of Wisdom on the one side and the embodied fertility of Eve on the other ... through her the Incarnation is accomplished and God becomes man. Thus she unites the celestial with the earthly, the divine with flesh ... Mary together with her Son is the supreme theophany, the revelation of God's ultimate will." ${ }^{48}$

Hildegard's appreciation of the female and maternal aspects of humanity informed her high Mariology and her proclamation of the feminine aspects of the divine. Assumptions about female inferiority, which she shared with her contemporaries, did not diminish her self-esteem or deflect her vision of God and Creation. Hildegard's appreciation of the gender of Wisdom and the maternal nature of God was unique in her time and much later. Her works remind us that twelfth-century attitudes-toward Mary or motherhood or any other matter-cannot be confined to a summary; they were as varied and complex as our own.

Just as medieval devotional and theological works that deal explicitly with Mary reveal the writers' assumptions about human motherhood, autobiographical writings that deal explicitly with human parents and children reveal the authors' perceptions of the

48. Newman, Sister of Wisdom, p. I 58. 
Virgin. Both genres disclose a wide range of associations between Marian ideologies and Christian motherhood. When Guibert of Nogent, taking Augustine's Confessions as a model, set out to write the story of his life, he thanked God for "a mother who was beautiful, yet chaste, modest, and steeped in the fear of the Lord." ${ }^{49}$ Like Augustine, Guibert was his mother's favorite child. The details of his birth were fixed in his imagination and sense of destiny. His mother labored all through Good Friday but was unable to give birth. His despairing family went to church to ask for Mary's help, and: "in the place of an offering this gift [was] laid upon the gracious Lady's altar: that should a male child be born, he should be given up to the religious life in the service of God and the Lady, and if one of the inferior sex, she should be handed over to the corresponding calling. At once a weak little being, almost an abortion, was born." ${ }^{50}$

When Guibert was twelve, his adoring mother left to enter religious life. Abandoned, he was furious and desperate: "She knew that I should be utterly an orphan with no one at all on whom to depend, for ... there was no one to give me the loving care a little child needs at such an age; though I did not lack for the necessities of food and clothing, I often suffered from the loss of that careful provision for the helplessness of tender years that only a woman can provide. ${ }^{51}$ As in Aelred's portrait of Jesus, Guibert saw himself not as the young man his society expected a twelve-year-old to be, but as a helpless child. His models failed him: Monica, as perceived and presented by Augustine, was entirely identified with her son; her spiritual destination was his conversion to Catholic Christianity. In the scheme of the Confessions, it would have been inconceivable for Monica to leave her

49. Guibert of Nogent, Self and Society in Medieval France: The Memoirs of Abbot Guibert of Nogent, ed. and trans. John F. Benton (New York: Harper \& Row, I970), p. 38. An insightful psychohistorical interpretation of Guibert and his mother is Nancy F. Partner, "The Family Romance of Guibert of Nogent" (unpublished paper, 1987). See also Mary M. McLaughlin, "Survivors and Surrogates: Children and Parents from the Ninth to the Thirteenth Centuries," in De Mause, History of Childhood, pp. Ior-I $8 \mathbf{I}$.

50. Guibert, Self and Society, p. 40.

5 I. Ibid., p. 42. 
son before his triumphant maturity. Later children of devout mothers experienced different outcomes, even when their mothers' behavior was consciously modeled upon that of Monica. ${ }^{52}$

In Guibert's adult judgment, his mother behaved correctly and deliberately in choosing God and her own salvation over her son's happiness. She was confronted with a clear choice between the responsibilities of physical motherhood and her spiritual health: "She knew for certain that she was a cruel and unnatural mother ... tenderness would then have been her ruin if she, neglecting her God, in her worldly care for me had put me before her own salvation." At twelve, however, Guibert had no mature perspective on his mother's choice. He reacted, predictably, by making trouble at school and at church, associating with rowdy companions, and indulging his depression by sleeping so much that he became ill. As he must have known it would, word reached his mother, who was "struck half dead by what she heard." She arranged for him to enter monastic life, and like Bernard he discovered in the cloister a resolution of his suffering. He did well until puberty, when "the life of this world began to stir my itching heart with fleshly longings and lusts to suit my stature." His mother intervened again, persuading him to confess his harmful feelings and to make amends. ${ }^{53}$ Then he settled down-if that can be said of such a troubled spirit, for he remained subject to violent and disturbing fantasies.

Guibert did grow up and turn his attention away from his mother, although he held on to the comforting notion that she never really left him, even after death. Her virtues remained available for his salvation: "Through her merit next to Jesus and His Mother and the Saints, while I still live in this evil world there remains to me the hope of that salvation which is open to all... And now that she is dead ... she is not ignorant of the miseries in which I am entangled, and, blessed as she is, she bewails my wanderings when she sees my feet go astray from the path of goodness marked out by her recurrent warnings. ${ }^{54}$ Among the

52. See Atkinson, "Your Servant, My Mother," esp. pp. I 55-1 58.

53. Guibert, Self and Society, pp. 74-75.

54. Ibid., p. 4 I. 
persistent ideologies of Christian motherhood is the conviction that mothers can-and therefore should-be good enough to "save" their children. In Guibert as in Bernard, confidence in maternal virtue and spiritual power was combined with an experience of loss and abandonment. The conflict was resolved in part through a passion for the mother of God, but also, in both men, by a profound and permanent distrust of women.

The best-known autobiographical writing of the twelfth century, Peter Abelard's "History of My Calamities," is in form and content very different from Guibert's memoirs; Abelard was more interested in adult achievement than in youthful development. He believed that his career had been determined by one crucial choice between scholarly and military pursuits. (Although he chose philosophy, he remained within the family tradition by becoming an intellectual champion-a fighter in the schools.) Abelard was his parents' first-born and his father's favorite child. Autobiographical writing was uncommon in that era; it may be that the experience of a parent's special attention persuaded both Guibert and Abelard that their individual experience must be of general interest.

Unlike Guibert and most other literate persons in the twelfth century, Abelard was a parent as well as a child, although his son Astralabe was handed over to relatives immediately after his birth. To judge from their famous letters, Abelard and Heloise were not much interested in their child, whose conception provided the occasion for their marriage. Pregnant, Heloise still insisted on the incompatibility of philosophy and marriage or, more accurately, of philosophy and parenthood: "What harmony can there be between pupils and nursemaids, desks and cradles, books or tablets and distaffs, pen or stylus and spindles? Who can concentrate on thoughts of Scripture or philosophy and be able to endure babies crying, nurses soothing them with lullabies, and all the noisy coming and going of men and women about the house? Will he put up with the constant muddle and squalor which small children bring into the home?" 55

55. Peter Abelard, The Letters of Abelard and Heloise, ed. and trans. Betty Radice (New York: Penguin Books, I 974), p. 7 I. 
Heloise rejected marriage as a degraded state unworthy of great love; Abelard insisted upon it from fear of reprisals. Neither of them used the existence or well-being of their child to make points in the discussion, nor was Heloise's entry into religious life discouraged on Astralabe's account. Their personal letters do not mention him, although after Abelard's death Heloise did ask the Abbot of Cluny to find a position for her son. ${ }^{56}$ None of this was extraordinary: twelfth-century children frequently were raised by relatives or by other families, and parents of young children did enter convents. It may be more significant that Astralabe did not figure in Abelard's attempt to console Heloise for her unhappiness by reminding her of her spiritual offspring: "What a hateful loss and grievous misfortune if you had abandoned yourself to the defilement of carnal pleasures only to bear in suffering a few children for the world, when now you are delivered in exultation of numerous progeny for heaven! Nor would you have been more than a woman, whereas now you rise even above men, and have turned the curse of Eve into the blessing of Mary. ${ }^{157}$ Abelard was following his favorite, St. Jerome-but Jerome had no children. In this passage, Astralabe's father seems to have forgotten that Heloise ever did bear a child; their living son was subsumed in the abstract representation of the curse of Eve.

It would be wrong to make too much of attitudes expressed or implied in the letters of Abelard and Heloise. Their shared conviction of Abelard's unique genius shaped all their activities and relationships, including parenthood. Neither of them was interested in motherhood as a concept or a reality, and the "nurturing, affectivity, and accessibility" attributed to mothers by contemporary monks ${ }^{58}$ were irrelevant to the relationship of Heloise and Astralabe. As parents, Heloise and Abelard did not ask very much of themselves. They found a home for their infant son, and when he was old enough, his mother helped him find a job. Among the legacies of these remarkable letters are an implicit warning

56. Peter the Venerable, letter to Heloise, in ibid., p. 287: "I will gladly do my best to obtain a prebend in one of the great churches for your Astralabe, who is also ours for your sake."

57. Ibid., p. I 50.

58. See Bynum, Jesus as Mother, p. I54. 
against overgeneralization from the writings of one group of people and a reminder that the notion of "motherhood" maintained by Cistercian monks was not necessarily shared by actual parents.

These world-famous lovers, obviously unaffected by Cistercian ideas about motherhood, were also untouched by the contemporary phenomenon known (much later) as "courtly love." Their passionate affair bore no resemblance to the idealized yearnings of the troubadours, and their gender roles reversed those of the courts, where young men worshiped unattainable, godlike older women. Abelard and Heloise belonged to Paris, not Provence; to the university and the cathedral, not the court. Furthermore, they existed, whereas no one is certain that courtly lovers ever lived outside of songs and stories. ${ }^{59}$

If courtly love had any reality beyond literary convention, it was confined to the new leisure class of twelfth-century Europe. An improved climate, increased food production, and substantial population increase made possible, for the first time in the West since late antiquity, the existence of persons with energy to spare from "work" - defined in the early Middle Ages as fighting, prayer, and agricultural labor. In some parts of Europe the constant burden of war and preparation for war was lightened by improvements in material conditions and by the long-term efforts of Church and Crown to channel and control endemic violence. The Crusades and the ecclesiastical peace movements limited the extent and duration of hostilities within Europe, and at certain courts war games and tournaments replaced battles. An aristocracy based on land-ownership and lineage rather than military achievement came into being; noble status could be reflected and displayed in manners and behavior, creating a market for discussions of style. The Art of Courtly Love does not necessarily describe real situa-

59. John F. Benton suggested that "The study of love in the middle ages would be far easier if we were not impeded by a term which now inevitably confuses the issues. As currently employed, 'courtly love' has no useful meaning. . . .I would therefore like to propose that 'courtly love' be banned from all future conferences"; see "Clio and Venus: An Historical View of Medieval Love," in The Meaning of Courtly Love, ed. Francis X. Newman (Albany: State University of New York Press, I 9681, p. 37 . 
tions, but it does mark a new attention to the social relations of upper-class men and women. ${ }^{60}$

Twelfth-century romance, like twelfth-century religious culture, was rooted in demographic change. Men no longer outnumbered women; upper-class men tended to marry late and to marry women much younger than themselves, creating a situation in which wives occupied a middle, mediating position between husbands and children. Young widowed mothers and distant older fathers were commonplaces of aristocratic life and literature; a son might easily become the "lord" of his widowed mother. Women who interceded for their children with authoritative men and women who bowed before their sons were familiar figures in feudal society as well as religious art. ${ }^{61}$ And with the establishment of primogeniture in some parts of Europe came increasing friction among the male members of aristocratic families. Eldest sons waited impatiently to inherit land and position; younger brothers were excluded from family estates and from the opportunity to take over their fathers' roles. Whether they entered religious life or became landless knights, they remained unmarried and childless, perpetually "young" and dependent on patronage. For these men, it may have been useful and appropriate to direct emotional energy toward unattainable women-the Virgin of the monks, or the knight's lady. An older woman with power derived from close relationship to a lord aroused complicated passions in the "young." 62

6o. Andreas Capellanus said, "If you should, by some chance, fall in love with a peasant woman, be careful to puff her up with lots of praise and then, when you find a convenient place, do not hesitate to take what you seek and to embrace her by force"; see The Art of Courtly Love by Andreas Capellanus I.9, trans. John Jay Parry (New York: Ungar, 1957), p. 24. Scholars debate whether this treatise is intended to be satirical, but in none of the courtly literature is there evidence of respect, let alone adoration, for peasant women.

6I. See David Herlihy, "The Generation in Medieval History," Viator 5 (1974), 347-364; also Doris Desclais Berkvam, Enfance et maternité dans la littérature français des XIIe et XIIIe siècles (Paris: Librairie Honoré Champion, I 981), p. I 39.

62. See Georges Duby, "Au XIIe siècle: Les 'Jeunes' dans la société aristocratique," Annales E.S.C. I 9 (I 964), 835-846. Christianne Marchello-Nizia argues that the energy of courtly love derived from the relationship of young men to older, more powerful men: the lady was a convenient device for the expression of a 
There are significant analogies between the cult of the Lady and that of the Virgin. In striking respects, not least her "maternal" characteristics (which included youth and beauty), the Lady of the troubadours resembled the Lady of hymns and prayers. What is not clear is the degree of resemblance between either lady and any real woman, the extent to which these phenomena influenced the status or experience of women, or the positive and negative implications of such influence. ${ }^{63}$ Was the figure of the Lady drawn from real situations, however limited in social context, or was it entirely a projection of fantasy, a creation of the "male gaze"? Julia Kristeva believes that a common origin in the male psyche links courtly love to the cult of the Virgin: "Even in its carnal beginnings courtly love had this in common with Mariolatry, that both Mary and the Lady were focal points of men's aspirations and desires." ${ }^{64}$ Whether or not she existed, the lady of secular and religious romance was a significant figure in twelfth-century Christian ideologies. Men brought to the new cults and the new romantic literature their filial-erotic passion for the older womanyoung mother. The Mary of the Planctus (the lament of the Virgin at the Cross) mourns Jesus her son, her lover, and her father. ${ }^{65}$ The intertwined feelings distinguished by twentieth-century people as "filial," "maternal," and "erotic" were expressed with the forceful passion that characterized the age.

\footnotetext{
passion that had more to do with ambition than with heterosexual love; see "Amour courtois, société masculin, et figures du pouvoir," Annales E.S.C. 36 ( I 98I), 969-982.

63. Once hailed as the supreme European contribution to the elevation of the status of women, courtly love (and "chivalry" in general) has recently been perceived as the base of that "pedestal" whose shadow is the stake. See E. William Monter, "The Pedestal and the Stake: Courtly Love and Witchcraft," in Becoming Visible: Women in European History, ed. Renata Bridenthal and Claudia Koonz (Boston: Houghton Mifflin, I977), pp. I I9-138; also Penny Schine Gold, The Lady and the Virgin: Image, Attitude, and Experience in Twelfth-Century France (Chicago: University of Chicago Press, I985).

64. Julia Kristeva, "Stabat Mater," in The Female Body in Western Culture, ed. Susan Rubin Suleiman (Cambridge, Mass.: Harvard University Press, I 986), p. Io6.

65. See John R. Secor, "The Planctus Mariae in Provençal Literature: A Subtle Blend of Courtly and Religious Tradition," in Spirit of the Court, ed. G. S. Burgess and R. A. Taylor (Cambridge: D. S. Brewer, 1985), pp. 321-326.
} 
After the middle of the eleventh century, literary images of Mary began to be affected by the interests and values of persons and groups outside the elites of court and cloister. The dignified Queen Mother of the early Middle Ages grew to incorporate the joyful young mother of Bethlehem and the tragic old woman at the Cross. Her portraits in paint and stone and song represented many phases of life: youth and beauty and tenderness, age and suffering and death. Monks continued to produce devotional and theological writings but turned also to genres and materials that were subject to influence from outside the monastic world. Mary's legend and cult received inspiration from new sources, including the collections of tales and legends that were gathered, written down, and circulated first inside and then far outside the monasteries and convents of western Europe.

Stories about the Virgin and her miracles, many of which originated in the East, had always been told in medieval Europe: as early as the sixth century, Gregory of Tours included six such tales in his Book of Wonders. By the late eleventh century, however, the context in which the stories were known was very different from that of the sixth. With the new literacy and interest in texts and in writing, monks and others began to record old stories-in Latin at first, but soon in the vernacular languages. Collections were made for the edification of monks and nuns, for the satisfaction of various communities and interest groups, and for the use of preachers and storytellers, who carried the tales far from their monastic homes. ${ }^{66}$ The interests of readers (more often, of listeners) became more significant in the construction of individual tales and the shaping of collections. "Reader response," the enthusiasm or indifference and special tastes of audiences, had an impact on the writers and tellers, and folkloric elements in the legends blended with monastic Mariology. The written miracles are not "popular" stories in the literary sense, for they were told to and by clerics and composed by a literate elite. Nonetheless, as the stories grew more and more "popular" in the sense of "wellliked," and widely available, audiences included lay people as well as monks, women as well as men, the nonliterate as well as the

66. See, e.g., Southern, "English Origin." 
educated, parents as well as celibates. Through their likes and dislikes, their values and concerns, these persons and groups took part in the construction of the new "Mary."

To read medieval "Miracles of the Virgin" is to be struck by the force and scope of Mary's powers in contrast to the helplessness and contingency of human beings. The men and women in the tales could not protect themselves or their children against sickness, death, or the consequences of sin. Their only recourse against harsh circumstances was to appeal to Mary, whose power was never in doubt, although she had to be persuaded to act. The keys to such persuasion were simple: supplicants had to prove singleminded devotion by prayer, constancy, and the performance of ritual acts of service. Mary did not come to the aid of suffering humanity out of the "unconditional love" ascribed to good mothers by modern psychologists; she required devoted attention. She did not expect heroism of her servants, or even good behavior, but she did demand faithfulness. ${ }^{67}$

Even a thief could be faithful, as demonstrated in the oftenrepeated story of "the hanged man":

There was once a very great robber, a most wicked man. ... Yet he had this good in him that he scrupulously fasted on bread and water during the vigil of the blessed Mary; and, when he went out to rob he used to salute her with such devotion as he could, asking her not to allow him to die in mortal sin.

But, being caught and brought to the gallows, he hung for three days and could not die. And when he called to those passing by and asked them to bring a priest, one came with the judge and the people and he was taken down from the gallows. Then said he that it was the blessed Virgin who kept him alive; and so he was set free, and afterwards he finished his life in praiseworthy fashion. ${ }^{68}$

67. The protagonists of the miracle stories, who ask for and receive help from the Virgin, are in that respect unlike courtly lovers, who were supposed to expect no favors in return for their devotion. See Frederick Goldin, "The Array of Perspectives in the Early Courtly Love Lyric," in In Pursuit of Perfection, ed. Joan M. Ferrante and George D. Economou (Port Washington, N.Y.: Kennikat Press, I 975), p. 55. The miracles represent a steady stream of transactions between Mary and her suitors: it is assumed that services will be exchanged.

68. Johannes Herolt, Miracles of the Blessed Virgin Mary: Johannes Herolt, trans. C. C. S. Bland (London: George Routledge, 1928), pp. 22-23. Other versions 
The thief's crimes paled in significance beside his devotion to Mary; she protected much more vicious sinners than he. ${ }^{69}$ The stories frequently end with the sinner's reform, but the reform is a by-product of the miracle, not its purpose. The stories are about Mary's mercy and power, not about the conversion of sinners.

Medieval paintings, theological writings, and visionary literature tend to emphasize Mary's mediating role: interceding for sinners, she uses her maternal influence to plead for mercy from Christ the Judge, or God the Father, who is the central figure. ${ }^{70}$ In the stories, Christ appears less frequently and then typically as a little child. Mary uses her own strength on behalf of her servantsshe spares the hanged man without help from her son. ${ }^{71}$ Like the warrior chiefs and patron saints of the early Middle Ages, she rewards her followers with her own gifts, taking care of her people. The ethical system of the tales has the character of the earlier period, when loyalty (from follower to lord) and generosity (from lord to follower) were normative virtues of the ruling class. Certainly Mary's power was understood to come from God and from her relationship to God, but in the tales she is active and independent: God remains in the background, or in his mother's arms.

The "miracles" include stories about kings and queens, knights and ladies, monks and nuns, criminals and poor old widows. In many of the tales, hierarchical assumptions and expectations are overturned, reinforcing the theme of the "Magnificat." A monk who knows no Latin and can learn none save the "Ave Maria" is despised by his brothers and superiors. When he dies, a fabulous

of the story are recounted in The "Stella Maris" of John of Garland, ed. Evelyn Faye Wilson (Cambridge, Mass.: Medieval Academy of America, I 946), pp. 2092 Io (hereafter Stella Maris).

69. Even perpetrators of incest and infanticide were protected: in several stories, when a mother who loves her son "too well" and bears a child-grandchild whom she kills, Mary saves her from execution for murder. See Stella Maris, pp. I76I 77 .

70. In artistic representations of the "double intercession," Mary displays her breast, Jesus his wounds, to persuade God to show mercy to sinners. See, e.g., Warner, Alone of All Her Sex, fig. 26; and Bynum, Holy Feast, figs. 28, 29. Cf. also Birgitta's vision of Mary pleading for the soul of Karl, in Chapter 5.

71. My interpretation differs from the thesis of Mary Vincentine Gripkey, The Blessed Virgin Mary as Mediatrix in the Latin and Old French Legend prior to the Fourteenth Century (Washington, D.C.: Catholic University of America, 1938). 
lily—the words "Ave Maria" engraved on every leaf-grows out of his grave. ${ }^{72}$ Humility triumphs; the mighty are put down; Mary's servants are justified.

The curious tale of "the hostage," which appears in many of the collections, illustrates the relationship of image and reality in medieval Europe. A mother whose child is in imminent danger of death prays for help to a statue of the Madonna. When no help comes, the woman snatches the image of the Christ Child from the statue and threatens to keep it until her own child is returned. Mary then sets to work to rescue the other mother's child. ${ }^{73}$ There is never any doubt about her ability to do so, but she must be begged or bullied into action. Hostages, usually children, were commonly given and taken in medieval Europe, and Mary did not become angry when her own child was taken-perhaps because she recognized maternal desperation. The question "Why doesn't she simply take back the Christ .Child?" was not asked or answered; after all, she did not take him back from the Cross.

The numerous children and infants in the stories present a poignant and complicated glimpse of medieval childhood. Children faced mutilation and death by fire and water, disease and accident; they were promised to the Devil by wicked or careless parents; they were neglected and abused as well as loved and cherished by parents and parental surrogates. Their presence in such numbers, with the assumption that they and their circumstances are touching and pitiful, argues against the "indifference" to children sometimes attributed to medieval adults. ${ }^{74}$ On the

72. In a pleasant rendering of this common theme, a feeble-minded priest was prohibited by his bishop, Thomas Becket, from saying mass. Mary ordered the priest restored to his office, reminding St. Thomas that she had once helped him repair his hair shirt. Becket obeyed immediately. See Caesarius of Heisterbach, Dialogue on Miracles, ed. G. G. Coulton and Eileen Power (London: George Routledge, r 929l, r:458-459.

73. In the Golden Legend version (p. 527), the mother returns the image of Christ, saying, "Thanks be to thee, Lady, for that thou has returned my only son to me; and now I do the same for thee."

74. In Centuries of Childhood: A Social History of Family Life, trans. Robert Baldick (New York: Knopf, I962), Philippe Ariès asserted that emotional ties between parents and children were weak until the seventeenth century. Similarly, in The Family, Sex, and Marriage in England, I 500-I 800 (New York: Harper \& Row, 1977), Lawrence Stone finds weak emotional bonds in English family life 
other hand, the stories do not supply evidence of careful and empathic parenting-far from it: Mary is a much more satisfactory parent than any of the adults.

The collection of miracles from the shrine of the Virgin of Chartres is a rich source of stories about children spared from horrible fates. Little Guillot discovered a girl from his village in the arms of a knight, who cut out the child's tongue so he would not report what he had seen. The Virgin restored the boy's speech three days after Easter and replaced his tongue at Pentecost. ${ }^{75} \mathrm{~A}$ babysitter gave a crying infant a piece of glass to play with; the child swallowed the glass, choked, and died. When the mother returned, she set out for Chartres with the baby, and even before they reached the shrine, it coughed up the glass and returned to life. ${ }^{76}$ A lady was godmother to her servant's child; when he drowned in a ditch, the lady promised to make an annual pilgrimage to Chartres if the child was restored to life, and she kept that promise to the end of her life. ${ }^{77}$ A couple longed for a baby, prayed to Mary, and had a son. The father went on a pilgrimage of thanksgiving, and while he was gone, the mother-bathing with the baby-fell asleep and let him drown. She was convicted of infanticide and sentenced to burning, but her husband returned in time to ask for Mary's help. Just before the fire was lit, the mother asked permission to kiss her dead infant one more time-and with

before early modern times, when the "closed domesticated nuclear family" replaced the "open lineage family" of the Middle Ages. Edward Shorter, in The Making of the Modern Family (New York: Basic Books, I 975 ), pp. I 68-204, extends Ariès's position and finds widespread parental, especially maternal, indifference to children well into the eighteenth and early nineteenth centuries. Recently, many historians have rejected this characterization of medieval families: e.g., David Herlihy, Medieval Households (Cambridge, Mass.: Harvard University Press, I 985 ), esp. pp. I I 2-I 30; David Hunt, Parents and Children in History: The Psychology of Family Life in Early Modern France (New York: Basic Books, I 970); Klaus Arnold, Kind und Gesellschaft in Mittelalter und Renaissance: Beitrage und Texte zur Geschichte der Kindheit (Cambridge, Mass.: Harvard University Press, I 985 ).

75. Miracles de Notre-Dame de Chartres, Pierre Kunstmann, ed., (Ottawa: Editions de l'Université d'Ottawa, I973), p. 36.

76. Ibid.

77. Ibid., p. 40. 
the kiss, he came back to life. Unable to leave well enough alone, the couple then set out on another pilgrimage of thanksgiving. ${ }^{78}$

The insecurity and real dangers of medieval childhood created powerful, persistent fantasies of protection and rescue by an omnipotent, loving mother. In that age of high infant and child mortality, parents could not protect their children from illness or from sudden, violent death. Through that harsh reality as well as the neglect and abuse common in every age, children suffered greatly. The tale of the child promised to the Devil by parents who later repent and regret the bargain appears in many collections; its representation of parental ambivalence must have struck a significant chord. At adolescence, the child-like the protagonist of a folktale-must go out into the world to find someone to rescue him; his parents cannot. Various powerful religious men (pope, patriarch, holy hermit) try to help, but in the end it is Marythe unambivalent mother-who saves him from the Devil. ${ }^{79}$ The innocent child, carrying the burden of his parents' sin, depends on the Virgin for redemption.

A significant number of the miracles that focus on children are also anti-Jewish tales; these themes were linked to each other and to Mary. Chaucer's Prioress told the well-known story of the little "clergeon," or schoolboy, in a version filled with the language and imagery of mothers and children. ${ }^{80}$ Like so many of the young protagonists, the clergeon was a widow's son and thus especially pitiful, vulnerable, and Christlike. As he walked to school through the ghetto he sang the "Alma Redemptoris": the Jews hated the song and killed the singer, cutting his throat and dropping his body in a sewer. When the widow could not find her child she prayed to Mary, who caused him to sing again (with his throat cut) until the Christians discovered the body and slaughtered the

78. Etudes sur les miracles de Notre-Dame par personnages, ed. Marguerite Stadler-Honegger (Geneva: Slatkine Reprints, I 975), pp. 51-53.

79. Several versions of the story appear in Stella Maris, pp. 201-202. In this folkloric tale, the hero must leave home to make his way in the world-thus the protagonist is inevitably male.

8o. Nikki Stiller makes this point in Eve's Orphans: Mothers and Daughters in Medieval English Literature (Westport, Conn.: Greenwood Press, I980), p. I I 4. 
Jews. ${ }^{81}$ The opposite number of the clergeon was the Jewish boy who innocently received the Eucharist with his Christian schoolmates. When his father found out, he put the child in a furnace, where the Virgin protected him from harm until he was rescued by a Christian friend. Then the father was killed-by crucifixion in some versions, and in others by taking his son's place in the furnace ${ }^{82}$ Representing all Jews, the father was made to suffer the fate of the "victim"- the young protagonist of the story or the Christ Child himself.

Anti-Jewish stories were written with grim zest; strategies for getting the better of Jews were reported with vengeful delight. In one of the nastiest tales, a young Jewish woman is seduced and made pregnant by a clerk. She fears her parents' anger, and the clerk persuades her to tell them that she is a virgin. He then speaks to them at night through a hollow reed, announcing that their daughter "hath conceived a son, who shall be the deliverer of your people Israel." (When that promise turns to bitter disappointment, according to the author, it is "fitting that they whose forefathers had been troubled by Herod by the birth of the Son of God ... should in these times be mocked.") The family and the community, believing the girl, take care of her and gather for the birth: "The hour came in which the unhappy one should be delivered, and there ensued the usual pains, groans, and cries. At last she brought forth an infant, not indeed the Messiah, but a daughter. When this became known, there was much confusion and trouble among the Jews, and one of them, wild with indignation, seized

8I. See Geoffrey Chaucer, "The Prioress's Tale," in The Riverside Chaucer, ed. Larry Benson (Boston: Houghton Mifflin, I987), pp. 209-2 I 2. Lester Little notes the association of money, Jews, and filth and the scatological details in medieval anti-Jewish writings; see Religious Poverty and the Profit Economy in Medieval Europe (Ithaca: Cornell University Press, I 978), esp. pp. 5 I-57.

82. This often repeated story was told by Evagrius Scholasticus in the sixth century about a glassblower's son-hence the furnace. It was translated from Greek in the ninth century and appears in most of the major collections (e.g., Stella Maris, pp. I 57-159). In a Middle English version, the boy fell in love with an image of Mary, which protected him in the furnace; he and his mother were saved (and converted) when the father was killed. See The Middle English Miracles of the Virgin, ed. Beverly Boyd (San Marino, Calif.: Huntington Library, 1964), pp. 3843 . 
the poor baby by the foot and dashed it against the wall. ${ }^{183}$ The very notion of a female Messiah, like that of a female pope, is inconceivable and contemptible, provoking hideous revenge on mother and infant.

In some stories Mary is represented as sympathetic to Jewish women as mothers, although her protection and their survival always depend upon their conversion. Vincent of Beauvais, among others, told of a woman in childbirth who saw a heavenly light and heard a voice telling her to call on Mary. She obeyed and gave birth safely and painlessly, but then had to leave her family and community and flee to a church for baptism and protection against the furious Jews. ${ }^{84}$ In another tale, a Jewish wife reported her husband for damaging a holy image-an image of Christ alone in the original Greek story but, in the later western version, an image of Christ in Mary's lap: by the twelfth century, certain kinds of story were unthinkable without the Virgin. Stories about the defacement of images generally ended with the capture and brutal punishment of the perpetrator, or with a conversion effected by the miraculous events surrounding discovery. Blood gushes from mutilated images, identifying the villains and demonstrating the powers of Mary and of Christ. ${ }^{85}$

The persistence and cruelty of anti-Jewish stories, which were widely circulated in the twelfth century and later, reflect a level of hatred and resentment maintained at simmering point and ready to break into overt violence when there was an incident, or a Crusade. Such stories held profound meanings for their audiences, for they were repeated over and over for centuries. Helpless, fragile children were presented as logical victims of Jewish aggression; they were identified with Jesus, portrayed in Christian teaching as the victim of the Jews. Children were seen as simple, innocent, and pure, like most of Mary's favorites. As the custodian of Christ's infancy, the only human being with whom he was physically intimate, Mary was also the custodian of all children

83. Caesarius, Dialogues, I:104-106.

84. Stella Maris, pp. I89-190.

85 . Ibid., p. 203. 
threatened by enemies of her son. The stories demonstrate the phenomenon of reversal, characteristic of hate literature: while Christians, especially Christian children, were depicted as the victims of Jews, Jews in medieval Europe were in fact being persecuted and killed by Christians. ${ }^{86}$

Jews were portrayed as faithless betrayers (of Christ); Mary's help and protection were contingent upon absolute fidelity to her. She brooked no competition with any other relationship or with ties of family, faith, or community and fiercely resisted her lovers' attempts to form other romantic associations. The boy who betrothes himself to Mary (usually to an image of Mary) and then is pushed toward marriage by insistent parents is always sharply reminded of the earlier vow. It most versions he escapes at the last minute and becomes a monk, preserving his commitment to the Virgin. ${ }^{87}$ Because she demanded utter fidelity, her consistent preference was for men in religious life, who were not distracted from her service. The monks who wrote down these stories presented themselves as Mary's favorites.

Although some of the legends were very old in the twelfth century, others were new, and many of the new stories originated in the cloister. A major theme of Caesarius of Heisterbach's Dialogue on Miracles was Mary's passion for the Cistercians, displayed by public protection of the order and intimate service to its members. She visited sick monks in the infirmary, blessing the virtuous brothers while they slept; one monk "saw in the dormitory a woman of wonderful beauty. She went round the beds of the sleepers and gave a blessing to each one, leaving out only one monk from whom she turned away her eyes ... he confessed that he had lain that night somewhat carelessly, relaxing from the strict rule of the order." The work and piety of good monks received Mary's encouragement, affection, and maternal care. Another reported seeing "Our Lady one night go around the choir while they were singing the psalms and wipe the faces of all the

86. Little makes this point in Religious Poverty, pp. $5 \mathrm{I}-52$.

87. This group of stories, varied in detail and setting, is one of the oldest; it descends from Roman tales of a young man betrothed to Venus. See Stella Maris, pp. I 6 I-I 66 . 
monks but two. Of these two, one soon became an apostate and it is not yet known what became of the other." ${ }^{18}$

The Virgin even recruited for the Cistercians. A monk struggled to persuade the abbot to accept a younger brother who was too young, according to the rules, but his brother was worried about him. The abbot's favorable decision was influenced by a vision of a lovely woman "before the monastery gate, holding a beautiful boy in her arms; and when he asked her whose boy it was, she replied, "He is the son of the monk_, " mentioning the older brother by name. ${ }^{89}$ Motherhood, in that context, was defined by care and protection, and the novice had two "mothers": Mary, and his older brother.

Caesarius's interlocutor asked whether the Virgin loved and visited religious women as well as men. The monk, claiming that she made no distinction based on sex, reported two visits to convents but quickly returned to stories about Mary's love for the monks. His indifference to the fate of women, even religious women, was revealed in the story of the youth who "violated a certain nun, and urged both by shame and fear, because she was nobly born, he took the vows in our Order. So that what the devil had prepared for his ruin became for him an occasion of salvation. ${ }^{\prime 90}$ Caesarius says nothing more about the nun, or about the spiritual and practical consequences of the seduction. His attitude illustrates the difficulties faced by women who wanted to be Cistercian nuns or were directed by Cistercian monks.

The often repeated tale of the pregnant abbess is usually set among nuns who suspect their superior of hypocrisy and resent her strictness. The abbess has an affair, becomes pregnant, and dreads the bishop's next visit. When she asks the Virgin for help, Mary delivers the child in secret and takes it to a hermit to be raised-again, a religious man is seen as a natural "mother." The reputation of the abbess and the convent is

88. Caesarius, Dialogue, I:471, 480 .

89. Ibid., p. 29.

90. Ibid., p. 38. 
preserved, and the child survives to become a monk and faithful servant of Mary. ${ }^{91}$

The story of Beatrice the sacristan, another erring nun, was as popular as that of the pregnant abbess. Beatrice ran away with a lover, leaving her keys on Mary's altar. Fifteen years later she returned, miserable and repentant, to find that "Beatrice" had been doing her work all the time, and achieving a reputation for sanctity as well. ${ }^{92}$ In this and several other stories, Mary changes her shape like a character in folklore. She appeared in one story as a soldier, taking the place of a knight who missed a tournament because he stopped to say his prayers at her shrine. When he finally arrived, he was welcomed with the news that he had won all the prizes. ${ }^{93}$ One could not lose through faithfulness to Mary.

Several popular stories featured Mary's milk, or her breastspowerful symbols and sources of power. The twentieth-century fascination with breasts as erotic objects was not characteristic of the twelfth century, when all children, in order to live, were fed by women. Breasts represented health and life and strength; in the case of Mary, who fed Christ, they also represented supernatural healing. Her milk cured sick or dying holy men, especially if the illness affected the lips, tongue, or throat: medieval people believed that any source of power worked most effectively in direct contact with the injured area. When important people like St. Bernard were involved, Mary's milk was a reward for devotion, but with simple monks or clerks it was restorative. I know of no miracles involving Mary's milk in which the beneficiaries were others than monks and priests; to the men who told these stories, the Virgin's milk was a resource for her favorite sons. ${ }^{94}$

91. In the version of this story told in Herolt's Miracles, p. 43, "this very boy, proving his fitness for it by his learning and his holy life, was the successor of that bishop." Such stories should be read also in the context of satirical writings in secular literature: see Graciela S. Daichman, Wayward Nuns in Medieval Literature (Syracuse, N.Y.: Syracuse University Press, I 986).

92. Herolt, Miracles, pp. 43-45.

93. Golden Legend, pp. 525-526.

94. Stella Maris, pp. I55-156. See also Paule-V. Bétérous, "A propos d'une des légendes mariales les plus répandues: Le 'lait de la Vierge," Bullétin de l'Association Guillaume Budé 4 (I 975), 403-4I I. Fulbert of Chartres, who wrote hymns and sermons for Mary and established the feast of her Nativity at Chartres, was one of the beneficiaries of this cure, according to William of Malmesbury in 
Christian motherhood has been profoundly influenced by the historical construction of the mother of God. Using scraps of evidence in the canonical gospels and the rich material of the apocrypha, early Christians built a towering female presence in theology, art, and worship. Her status was assured by developments in Christology: the God-man saved all men and women through humanity derived from his mother, and in learned writing and preaching, Mariology conformed to Christology. The figure of Mary also had aspects independent of Christology, gradually acquiring certain functions and attributes of the mother-goddesses of the old religions. In the Virgin, Christians discovered and made manifest in art and worship the powers of a sacred female being common to many of the world's religions.

In the West in the early Middle Ages, Mary was perceived as a queen-empress, presiding in a distant heaven with God the Father and God the Son; the healing and cherishing, erotic and reproductive powers of the sacred were left to more immediate saints. Amid the rapid economic, social, and cultural development of the eleventh century, Mary became again an immediate and vital presence in the experience and imagination of her devotees. The Virgin of the Gothic cathedrals, the loving Madonna of painting and sculpture, was represented in many kinds of religious literature, from the treatises and prayers that arose in reformed monastic orders to stories that circulated far outside the cloister. Men like St. Anselm and St. Bernard brought a new intensity to their praise of Mary, converting Mother and Queen into Lover and Bride. The Mary legends, shaped in part by the values and experience of lay people, reflected a similar intensity: their Mary is passionate, beautiful, and exclusive-an exemplary mother to small children, a jealous lover and devoted helpmate of religious men. The major contributions of twelfth-century Christians to the history of motherhood in the West were made through the cult of the Virgin, which stimulated a new recognition of the erotic aspects of mother love and appreciation of its passionate intensity.

Gesta regum anglorum, ed. William Stubbs (London: Rolls Series 90, I887-89), 2:34I. 